\title{
Acute toxicity of the water-soluble fraction of diesel in Prochilodus vimboides Kner (Characiformes: Prochilodontidae)
}

\author{
Celina Alcoforado Santos ${ }^{1}$, Dominik Lenz ${ }^{1}$, Geisamanda Pedrini Brandão ${ }^{2}$, Adriana \\ Regina Chippari-Gomes ${ }^{1}$ and Levy Carvalho Gomes ${ }^{1}$
}

Diesel oil can be a source of contamination in aquatic environments, mainly as a result of spills. The effects of the watersoluble fraction of diesel (WSF) on Prochilodus vimboides were assessed. Fish were exposed to three different WSF dilutions for up to $96 \mathrm{~h}$ and were compared to a control group. Damages in the fragments of DNA were analyzed using the Comet assay. The presence of erytrocyts abnormalities was assessed by micronucleus test. Aspartate aminotransferase (AST) and alanine aminotransferase (ALT) activity and the accumulation of copper in gills were also analyzed. Fish exposed for $96 \mathrm{~h}$ had higher rates of damage than those exposed for $24 \mathrm{~h}$. There was no significant difference regarding the presence of micronuclei between exposed and control fish and between 24-h and 96-h exposures. For AST, no significant difference was observed between samples collected at the two exposure times. Fish exposed to a 1:100 dilution of WSF showed higher activity of the enzyme ALT than the control fish after a 24-h exposure period. There was no bioaccumulation of copper in the gills. We conclude that the genotoxic effects of WSF in the cells are more evident in P. vimboides during an acute exposure.

O óleo diesel pode ser uma fonte de contaminação em ambientes aquáticos, principalmente como resultado de derrames acidentais. Foram avaliados os efeitos da fração solúvel do óleo diesel (FSO) em Prochilodus vimboides. Os peixes foram expostos a três diferentes diluições da FSO por até 96 horas e comparados com um grupo controle. Os danos nos fragmentos de DNA foram analisados utilizando o ensaio Cometa. A presença de anormalidades nos eritrócitos foi avaliada pelo teste do micronúcleo. A atividade da Aspartato aminotransferase (AST) e alanina aminotransferase (ALT) e da acumulação de cobre nas brânquias também foram analisados. Os peixes expostos por $96 \mathrm{~h}$ tiveram maiores taxas de danos do que aqueles expostos por $24 \mathrm{~h}$. Não houve diferença significativa quanto à presença de micronúcleos entre os peixes expostos e controle e entre 24 e 96 h exposições. Para AST, não foi observada diferença significativa entre as amostras coletadas em dois tempos de exposição. Os peixes expostos a uma diluição de 1:100 do FSO apresentaram maior atividade da enzima ALT do que os peixes do controle após um período de exposição de 24 horas. Não houve bioacumulação de cobre nas brânquias. Os efeitos genotóxicos nas células foram os mais evidentes em $P$. vimboides durante a exposição aguda a FSO.

Key words: Comet assay, Curimba, Diesel, Micronucleus.

\section{Introduction}

In recent years, the rivers of South America have been contaminated by diesel oil. This oil derivate exhibits low solubility in water, and the water-soluble fraction contains several toxic constituents like hydrocarbons and metals. The water-soluble fraction (WSF) of crude oil and their derivatives products contains a mixture of polycyclic aromatic hydrocarbons (PAHs), monoaromatic hydrocarbons often referred to as BTEX (benzene, toluene, ethylbenzene and xylenes), phenols and heterocyclic compounds, containing nitrogen and sulfur (Saeed \& Al-Mutairi, 1999), and also heavy metals (Rodrigues et al., 2010). The most frequently metals found in the diesel oil and lubrificant oils were copper and nickel (Silveira et al., 2006). Due their toxicity and potential to accumulate, copper deserves more attention among then.

The polyaromatic hydrocarbons (PAHs), such as naphthalene, fluorine and phenanthrene (Simonato et al., 2008) are among the chemical components of diesel oil that pose the greatest environmental hazard (Lee \& Anderson, 2005). The acute toxicity of hydrocarbons is known to cause damage in several organisms, including in their DNA (Zhang et al., 2004; Kennedy \& Farrel, 2005). Comet assay it is a rapid, sensitive and relatively inexpensive method providing the opportunity to study DNA damage (including oxidative damage), repair and cell death (apoptosis) in different cell types without prior knowledge of

${ }^{1}$ Universidade Vila Velha, Laboratório de Ictiologia Aplicada, Rua Comissário José Dantas de Melo, 21, 29102-770 Vila Velha, ES, Brazil. levy.gomes@uvv.br

${ }^{2}$ Universidade Federal do Espírito Santo, LabPetro, Av. Fernando Ferrari, 514, 29075-910 Vitória, ES, Brazil. 
karyotype and cell turnover rate (Jha, 2008). For that this analyze has been shown to be a relatively sensitive and broad specificity indicator of genotoxic pollutant exposure (Mitchelmore \& Chipman, 1998). The micronucleus test is one of the most popular tests of environmental genotoxicity, has been used as an indicator of cytogenetic damage for more than 30 years and is considered to be a well-established indicator of genotoxicity (Fenech et al., 2003; Çavas et al., 2005). The PAHs also cause damage to fish tissues thereby leading to leakage of enzyme to the extracellular fluid increasing the serum activity of several enzymes like those from amino group (Adeyemi et al., 2009).

Prochilodus vimboides is a freshwater migratory fish species from Southern Brazil used as human food that present high sensitivity to metal contamination (Gomes et al., 2009). This fish species were subjected to fast exposures to contaminant dissolved in the water due their ability to escape and the lotic characteristics of their habitat. This study tested the hypothesis that Prochilodus vimboides show several genetic and tissue damage and has potential to accumulate copper even under acute exposure to WSF.

\section{Material and Methods}

Animals and acclimation. Prochilodus vimboides juveniles $(\mathrm{n}=72)$ were obtained from the Instituto Federal de Colatina, Espírito Santo, Brazil. The fish $(9.83 \pm 5.84 \mathrm{~g} ; 9.48 \pm 1.60 \mathrm{~cm}$; mean $\pm \mathrm{SD}$ ) were transported to the laboratory and kept in a $500-\mathrm{L}$ tank for 15 days, with water supplied by local water company and constant aeration.

In the tanks, fish were fed twice a day on a $40 \%$ protein pellet fish food (Nutriave, ES, Brazil). During acclimation, the physicochemical parameters of the water were monitored every 3 days using a multiparameter YSI 85 instrument and a digital $\mathrm{pH}$ meter. The parameters analyzed were $($ mean $\pm \mathrm{SD})$ temperature $\left(25.6 \pm 0.4^{\circ} \mathrm{C}\right)$, conductivity $(148.6 \pm 33.3 \mu \mathrm{S} / \mathrm{cm})$, dissolved oxygen $(6.2 \pm 0.4 \mathrm{mg} / \mathrm{L}), \mathrm{pH}(7.3 \pm 0.2)$ and total hardness $\left(27.75 \pm 0.01 \mathrm{mg} / \mathrm{L} \mathrm{CaCO}_{3}\right)$.

Preparation of the diesel water-soluble fraction. Commercial diesel oil (B2; density $0.832 \mathrm{~g} / \mathrm{cm}^{3}$ ) was purchased at a gas station. The container used to transport the diesel oil was lined with a black plastic bag to prevent any sort of alteration in its physiochemical parameters.

The water-soluble fraction of diesel (WSF) was prepared strictly according to the methodology described by Singer et al. (2000). Initially, a 5-g sample of diesel oil was weighed and transferred to a 1-L volumetric flask, which was filled with water from the acclimation tank to the 1-L mark. The water and oil solution was then transferred to an amber flask and shaken for 24-h, with care to prevent the formation of a vortex. The resulting WSF was removed using a pipette. The composition of the WSF was analyzed by gas chromatography (Perkin Elmer, Clarus 500) to detect total PHA, benzene, toluene, xylene, naphthalene, phenanthrene and fluorene. A sample of WSF was digested and analyzed in a graphite furnace atomic absorption spectrometer (EAA-
FG; GBC Avanta 932, IL, USA) to establish copper and nickel contents.

Toxicity tests. After the acclimation period, the fish $(\mathrm{n}=72)$ were transferred to 72 aquaria (2-L) with constant aeration. One fish was placed in each aquarium. Four treatments were defined according to WSF dilutions: 1:1,000; 1:500; 1:100 and one control group. WSF dilutions were chosen based on previous studies on fish exposure to WSF (Santos et al., 2010). In total, the exposure period lasted $96-\mathrm{h}$ and fish were sampled at 24 and $96-\mathrm{h}(\mathrm{n}=9$ fish per treatment on each time). Half the contents of aquaria containing fish exposed to the three different WSF dilutions for 96-h was replaced at 48-h during the exposure period by an equal volume of the respective WSF dilution (Santos et al., 2010).

At the end of the experiment, fish were killed in a solution containing a lethal concentration of benzocaine $(300 \mathrm{mg} / \mathrm{L})$. Blood samples were collected from each specimen by caudal vein puncture using heparinized syringes. This methodology is in accordance with the procedures described in the guide for the use of fish in research published by the American Fisheries Society (Nickum et al., 2004). The gills of the fish were excised and placed in a refrigerator at $-20^{\circ} \mathrm{C}$ for copper bioaccumulation analysis.

During the experiment, water physicochemical parameters were measured using a multiparameter YSI 85 instrument. The measurements obtained included (mean $\pm \mathrm{SD}$ ) temperature $\left(25.5 \pm 0.3^{\circ} \mathrm{C}\right)$, dissolved oxygen $(6.9 \pm 0.5 \mathrm{mg} /$ L), conductivity $(87.5 \pm 2.9 \mu \mathrm{S} / \mathrm{cm}), \mathrm{pH}(7.05 \pm 0.3)$ and total hardness $\left(28 \pm 0.3 \mathrm{mg} / \mathrm{L} \mathrm{CaCO}_{3}\right)$.

Comet assay. The blood samples were diluted 1:120 (v/v) with RPMI 1640 medium and used immediately. The alkaline Comet assay was performed as described by Tice $e t$ al. (2000). Briefly, 5 $\mu \mathrm{L}$ of each diluted blood sample was added to $95 \mu \mathrm{L}$ of $0.75 \%$ (w/ v) molten low melting point agarose, and a portion of the mixture was spread on a microscope slide pre-coated with $1.5 \%(\mathrm{w} / \mathrm{v})$ normal melting point agarose and covered with a coverslip. After the agarose solidified, the coverslips were removed, and the slides were immersed in a lysis solution $(2.5 \mathrm{M} \mathrm{NaCl}, 100 \mathrm{mM}$ EDTA and 10 mM Tris, $\mathrm{pH} 10.0-10.5)$ containing $1 \%$ Triton X100 and $10 \%$ DMSO. The slides were kept frozen in lysis solution $\left(4^{\circ} \mathrm{C}\right)$, and protected from light for at least $2 \mathrm{~h}$ and at most $3 \mathrm{~h}$. Subsequently, slides were incubated in freshly prepared alkaline buffer $(300 \mathrm{mM} \mathrm{NaOH}$ and $1 \mathrm{mM}$ EDTA, $\mathrm{pH} \geq 13$, which was experimentally determined) for $20 \mathrm{~min}$ for DNA unwinding. Electrophoresis $(15 \mathrm{~min}$ at $300 \mathrm{~mA}$ and $25 \mathrm{~V}[0.8 \mathrm{~V} / \mathrm{cm}])$ was performed in the same buffer. Every step was carried out under indirect yellow light. After electrophoresis, slides were neutralized in $400 \mathrm{mM}$ Tris ( $\mathrm{pH} 7.5)$, rinsed three times in distilled water, and left to dry overnight at room temperature. Slides were then fixed for $10 \mathrm{~min}$ in $15 \%$ trichloroacetic acid (w/v), $5 \%$ zinc sulfate $(\mathrm{w} /$ $\mathrm{v})$, and $5 \%$ glycerol $(\mathrm{v} / \mathrm{v})$, rinsed three times in distilled water, and dried for $2 \mathrm{~h}$ at $37^{\circ} \mathrm{C}$. The dry slides were rehydrated for $5 \mathrm{~min}$ in distilled water and then stained ( $5 \%$ sodium carbonate $(\mathrm{w} / \mathrm{v})$, $0.1 \%$ ammonium nitrate $(\mathrm{w} / \mathrm{v}), 0.1 \%$ silver nitrate $(\mathrm{w} / \mathrm{v}), 0.25 \%$ 
tungstosilicic acid, $0.15 \%$ formaldehyde $(\mathrm{w} / \mathrm{v})$, freshly prepared in the dark) with constant shaking for $35 \mathrm{~min}$. The stained slides were rinsed twice with distilled water and then submerged in the stop solution ( $1 \%$ acetic acid), rinsed again, and immediately coded for analysis. To calculate image length, 200 cells from each fish were randomly chosen (100 from each duplicate slide) and analyzed under an optical microscope $(100 \times$ magnification). We analyzed 200 cells per animal and utilized the following visual classification groups based on the migration of DNA fragments from the nucleus: class 0 (no damage), class 1 (little damage less or equal to the diameter of one nucleus), class 2 (medium damage - greater than the diameter of two nuclei), class 3 (extensive damage - greater than two times the diameter of one nucleus) and class 4 (apoptosis - cell death) (Collins et al., 1995; Kobayashi et al., 1995). The data are presented as the frequency of cells per class of damage. The comet score (CS) for each fish was calculated as the sum of the number of nucleoids observed in each damage class multiplied by the value of its respective damage class $(0,1,2,3$, or 4$)$. The results are expressed as comet score for each treatment group, where 0 represents the absence of damage and 400 indicates the highest damage score.

Micronucleus test. Peripheral blood samples obtained from the caudal vein of the specimens and smeared on clean slides. Slides were left to dry in the laboratory environment overnight, and then the smears were fixed in methanol for $15 \mathrm{~min}$, stained for $20 \mathrm{~min}$ with $5 \%$ (w/v) Giemsa, washed with distilled water and left to dry in the laboratory. After drying, 2,000 erythrocytes per fish (1,000 from each duplicate slide) were analyzed for the presence of micronuclei at $100 \times$ magnification under a light microscope (Al-Sabati and Metcalfe, 1995).

\section{Aspartate aminotransferase and alanine aminotransferase} (AST and ALT). The blood samples were centrifuged at 151.2 $\mathrm{x} g$ for $10 \mathrm{~min}$. The plasma was used to quantify the enzyme activity of aspartate aminotransferase (AST) by kinetic method. The AST catalyzes the transfer of amino groups of aspartate for $\alpha$-ketoglutarate, leading to formation of glutamate and oxalacetate. Oxalacetate in the presence of $\mathrm{MDH}$ reacts with NADH, reducing itself into Malate NADH oxidates to NAD + . The rate of oxidation is proportional to AST activity in the sample. The alanine aminotransferase (ALT) was also determined according to kinetic method. The ALT catalyzes the transfer of amino groups of alanine for $\alpha$ ketoglutarate, leading to formation of pyruvate and glutamate. Pyruvate in the presence of LDH reacts with NADH, reducing the Lactate and oxidizes NADH to NAD+. The rate of oxidation is proportional to ALT activity in the sample. Both enzymes were analyzed using the enzyme kit Bioclin (Bioclin, MG, Brazil) and a UV/Visible spectrophotometer.

Copper bioaccumulation. The digested samples were analyzed in a graphite furnace atomic absorption spectrometer (GF AAS - ZEEnit 700, Analytik Jena, Germany) equipped with a transversely heated graphite atomizer (THGA) and a transverse background corrector system based on the Zeeman effect (2- field mode with maxima strength of 1.0 Tesla). An autosampler MPE 60, platform graphite tubes and a hollow cathode lamp $(\mathrm{Cu}$-Analytik Jena - operated at a current of $2.0 \mathrm{~mA})$ were used. The measurements were performed in peak area $(\mathrm{N}=3)$ at $328.8 \mathrm{~nm}$, with the spectral band pass at $0.8 \mathrm{~nm}$. The results were expressed as $\mu \mathrm{g} \mathrm{Cu} / \mathrm{g}$ fresh tissue. Several metals were assessed in WSF, such as nickel and copper. It was choose to study the bioaccumulation of copper in the gill of the fish because of its toxicity and their abundance detected in the analysis of the WSF.

Statistical analysis. All obtained data were submitted to a Kolmogorov-Smirnov test to verify their distribution. The micronucleus and damage frequencies results did not presented a normal distribution even after log transformation. Therefore, the micronucleus and damage frequencies in the erythrocytes of the fish exposed to dilutions of WSF were compared to the respective control fish using a Kruskal-Wallis ANOVA and a Dunn's test $(\mathrm{p}<0.05)$. Difference between the two exposure times ( 24 and $96 \mathrm{~h}$ ) for a particular dilution were compared using a Mann-Whitney test. The CS, copper concentration in the gills as well as AST and ALT of the fish exposed to the WSF solutions were compared to the respective controls using ANOVA and a Dunn's test $(\mathrm{p}<0.05)$ and difference between the two exposure times ( 24 and $96 \mathrm{~h}$ ) for a particular dilution were compared using a T-test.

\section{Results}

During the experiment there was no mortality and no change in fish behavior during the exposure.

Diesel water-soluble fraction content. The composition of the WSF was: total PHA - $4.3 \mathrm{mg} / \mathrm{L}$, benzene $-0.10 \% \mathrm{v} / \mathrm{v}$, toluene $0.56 \% \mathrm{v} / \mathrm{v}$, xylene $-2.0 \% \mathrm{v} / \mathrm{v}$, naphthalene $-4.6 \mathrm{mg} / \mathrm{L}$, phenanthrene - $0.31 \mathrm{mg} / \mathrm{L}$ and fluorene $-0.24 \mathrm{mg} / \mathrm{L}$. The copper and nickel contents were $3.904 \mathrm{ng} / \mathrm{mL}$ and $4.00 \mathrm{ng} / \mathrm{mL}$, respectively.

Comet assay. With respect to class 1 damage (which defines little damage to the DNA of erythrocytes), except for $P$. vimboides exposed to a 1:1,000 dilution of WSF for 24-h, no significant differences were observed in fish treated with the other WSF concentrations (1:500 and 1:100) in comparison to the respective controls. For class 2 damage (which denote moderate damage), P. vimboides exposed to 1:500 and 1:100 WSF presented the highest number of damaged cells in comparison to the respective controls. For class 3 (extensive damage), only the fish exposed to 1:100 WSF presented significantly more damaged cells in comparison to the control. For class 4 (apoptosis feature), the median was zero for all WSF dilutions, with no significant differences in comparison to the control (Table 1).

With regard to the 96-h exposure period, $P$. vimboides exposed to all WSF dilutions $(1: 1,000,1: 500$ and 1:100) presented a lower occurrence of class 0 cells in comparison to the respective controls; however, a significant difference in comparison to controls was observed for the fish exposed 
to the 1:100 dilution of WSF. Fish exposed to this WSF concentration presented lower frequencies of class 1 cells compared to the respective controls, and these differences were statistically significant. On the other hand, the fish exposed to 1:500 and 1:100 dilutions of WSF presented higher frequencies of class 2 and 3 cells compared to the respective controls. The fish exposed to these WSF dilutions also presented significantly higher numbers of class 4 cells than their respective controls (Table 1).

The fish exposed to all WSF dilutions $(1: 1,000,1: 500$ and 1:100) for 24 - and $96-\mathrm{h}$ treatments presented higher CS than the control fish (Fig. 1). Fish exposed to WSF for 96-h presented significantly higher CS than those exposed for 24-h.

Micronucleus test. The micronucleus median was 0 for all dilutions and times of exposure. There were no significant differences in the micronuclei in erythrocytes of $P$. vimboides exposed to WSF dilutions $(1: 1,000,1: 500$ and 1:100) for 24 -h or 96-h compared to the respective control. Similarly, there was no difference in fish exposed to a particular WSF dilution for either exposure times.

Aspartate aminotransferase and alanine aminotransferase (AST and ALT). The AST activity varied between 290 and 390 $\mathrm{URF} / \mathrm{mL}$. No significant differences were observed in AST activity in P. vimboides exposed to the WSF dilutions 1:1,000, 1:500 or $1: 100$ for $24-\mathrm{h}(\mathrm{p}=0.121)$ or $96 \mathrm{~h}(\mathrm{p}=0.572)$. Similarly, no significant differences were observed in fish exposed to a particular WSF dilution between the two exposure times (control: $p=0.428$ and $\mathrm{F}=0.622 ; 1: 1,000: \mathrm{p}=0.312$ and $\mathrm{F}=1.088 ; 1: 500: \mathrm{p}=0.789$ and $\mathrm{F}$ $=0.740$; and $1: 100: \mathrm{p}=0.365$ and $\mathrm{F}=0.870$ ).

Only the fish exposed to the 1:100 WSF solution for 24-h presented higher activity values of ALT (410 URF/mL) compared to the control (181 URF/mL). For the 96-h exposure period, no significant differences were observed between WSF dilutions and controls $(p=0.946)$. Similarly, no significant differences were observed when the two exposure times are

Table 1. DNA damage frequency (\%) in erythrocytes of Prochilodus vimboides exposed to different water soluble fractions of diesel $(1: 1,000,1: 500$ and 1:100) for 24 and $96 \mathrm{~h}$. Median values are presented. *: Significant difference in one dilution in comparison to respective controls using a KruskalWallis ANOVA and the Dunn's test $(\mathrm{p}<0.05)$.

\begin{tabular}{lccccc}
\hline & \multicolumn{5}{c}{ Comet class } \\
\cline { 2 - 6 } Dilution & 0 & 1 & 2 & 3 & 4 \\
\hline 24-h exposure & & & & \\
Control & 69.50 & 30.00 & 0.00 & 0.00 & 0.00 \\
$1: 1000$ & 30.00 & $43.00^{*}$ & 24.00 & 0.00 & 0.00 \\
$1: 500$ & $26.00^{*}$ & 32.00 & $41.00^{*}$ & 0.50 & 0.00 \\
$1: 100$ & $21.50^{*}$ & 31.50 & $44.00^{*}$ & $2.50^{*}$ & 0.00 \\
\hline 96 -h exposure & & & & & \\
\hline Control & 67.00 & 32.50 & 0.50 & 0.00 & 0.00 \\
$1: 1000$ & 14.50 & 57.50 & 26.50 & 0.50 & 0.00 \\
$1: 500$ & $10.50 *$ & 25.00 & $48.00^{*}$ & $15.50^{*}$ & $0.50 *$ \\
$1: 100$ & $6.50^{*}$ & $15.50^{*}$ & $49.00^{*}$ & $45.25^{*}$ & 0.50 \\
\hline
\end{tabular}

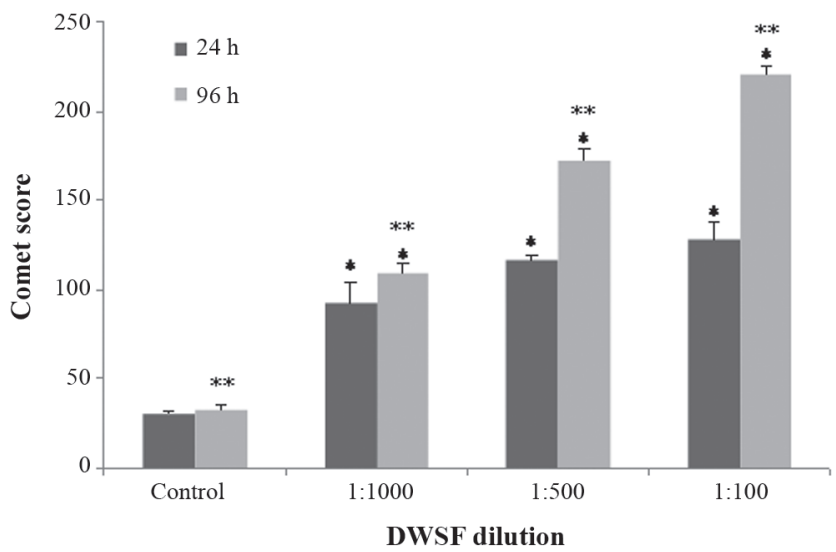

Fig. 1. Comet score (CS) in Procholidus vimboides exposed to different water soluble fractions of diesel $(1: 1,000,1: 500$ and $1: 100)$ for 24 and $96 \mathrm{~h}$. The results are expressed as the mean \pm standard deviation. *: Significant difference between one dilution and the respective control after 24- or 96-h exposure periods using an ANOVA and the Dunn's test $(\mathrm{p}<0.05)$. ** Significant difference between the two exposure times (24 and $96 \mathrm{~h}$ ) for the same dilution using the T- test $(\mathrm{p}<0.05)$.

compared in terms of a particular WSF concentration, (control: $\mathrm{p}=0.442$ and $\mathrm{T}=-0.790 ; 1: 1,000: \mathrm{p}=0.361$ and $\mathrm{T}=-0.941 ; 1: 500$ : $\mathrm{p}=0.302$ and $\mathrm{T}=-1.071$; and $1: 100: \mathrm{p}=0.204$ and $\mathrm{T}=1.329$ ).

Copper bioaccumulation. Copper in the gills ranged between 23 and $33 \mu \mathrm{g} / \mathrm{g}$ fresh tissue. There was no significant differences in the copper concentration in the gills of the $P$. vimboides exposed to the three WSF dilutions $(1: 1,000,1: 500$ and $1: 100)$ for $24-\mathrm{h}(\mathrm{p}=$ $0.160)$ or $96-\mathrm{h}(\mathrm{p}=0.356)$. Similarly, there was no difference in fish exposed to a particular WSF dilution for either exposure times (control: $p=0.603$ and $F=0.286 ; 1: 1,000: p=0.881$ and $F=0.234$; $1: 500: p=0.248$ and $F=1.472$; and $1: 100: p=0.125$ and $F=2.668$ ).

\section{Discussion}

Comet assay. According to Maria et al. (2004), the process of biotransformation of PAHs in fish, often, converts these xenobiotics into reactive intermediate substances, which are highly toxic and cause an oxidative damage to DNA. At the cellular level, a sensitive indicator of genetic damage is the breakage of DNA that form fragments of different lengths and can be detected by Comet assay (Buschini et al., 2004). According to Speit and Hartmann (1995), several mechanisms have been proposed to explain DNA breaks in vertebrates, particularly in the case of exposure to PAHs. The WSF is composed mainly of PAHs, probably these compounds have influenced the damages observed in the cells of $P$. vimboides.

In the present study, the Comet assay revealed high mean frequencies of damaged cells detected in the exposed groups in comparison to control fish. When samples collected from $P$. vimboides exposed to WSF for 24-h were compared to controls, 
it was observed that the lower the WSF dilution was (1:100) the higher the number of class 3 (extensive damage). In samples treated with 1:100 or 1:500 WSF for 96-h, class 4 (apoptosis feature) were detected. These data show the occurrence of damaged cells and demonstrate the high genotoxicity of WSF, which confirms previous results of genotoxic damage in $P$. lineatus exposed to WSF (Vanzella et al., 2007).

Lemos et al. (2005) showed the efficacy of the Comet assay in Tilapia rendalli. The organisms kept in a contaminated environment presented twice the amount of CS compared to the control group. In another study, high CS have also been reported in Zoarces viviparus collected in an estuary where the sediment was contaminated with several compounds, such as PAHs (Frenzilli et al., 2004). Pandrangi et al. (1995) showed an increase in DNA damage in erythrocytes of the fish species Ameirurus nebulosus and Cyprinus carpio captured in waters contaminated with PAHs. The results showed that CS was an efficient approach to evaluate WSF toxicity in $P$. vimboides at both exposure periods evaluated (24- and 96-h).

Micronucleus test. The importance of nuclear changes as biomarkers of genotoxic damage in fish has been demonstrated both in the laboratory and in the field (Al-Sabati \& Metcalfe, 1995; Çavas \& Ergene, 2003). In this scenario, the micronucleus test is now a key tool in the assessment of environmental pollution and of the effects of different compounds on organisms (Ergene et al., 2007). The data obtained in the micronucleus test in several fish species confirm the usefulness and efficiency of this test in biomonitoring studies (Rao et al., 1997). According to Buschini et al. (2004), micronuclei are considered the endpoint of genotoxicity because they may emerge after cell division. However the results of this study was not in agreement to the above affirmation, as $P$. vimboides exposed to WSF do not presented a significantly increase in $\mathrm{MN}$ values.

Prochilodus lineatus acute and subchronically exposed to WSF, revealed a sharp increase in micronucleus frequencies mainly in subchronic (15 days) exposure (Vanzella et al., 2007). Sea horse (Hippocampus reidi) showed an increase in MN frequency after 96-h of exposition to WSF (Santos et al., 2010). In the present study, there was no increase in micronucleus frequencies in $P$. vimboides exposed to a WSF for 96-h. According to Udroiu (2006) 96$\mathrm{h}$ was sufficient to detect an increase in $\mathrm{MN}$, therefore the main explanation to the obtained results was the low genotoxic damage of the tested dilutions.

Aspartate aminotransferase and alanine aminotransferase AST and ALT). AST and ALT are enzymes that catalyze the transfer of one amino group $\left(\mathrm{NH}_{3}\right)$ and act both in the degradation and in the biosynthesis of amino acids. These enzymes have been used as indicators of damage in tissues or metabolic changes induced by contaminants (Teles et al., 2003) mainly in liver. Adeyemi et al. (2009) reported that high levels of these serum enzymes are seen in cases of cellular death arising from toxicity.
Previous results showed that fish exposed either PAHs (Adeyemi et al., 2009) or metals showed an increase in the ALT and AST activity, therefore both WSF constituents can cause tissue damage. The absence of differences in ALT and AST in the present study in most $P$. vimboides samples was also observed in liver of Oreochromis mossambicus (Dangé, 1986) acutely exposed to PAHs. On the other hand Oreochromis mossambicus exposed to PAHs for 10 weeks presented a significantly alteration on ALT and AST activity in the liver (Dangé, 1986). These findings suggest that acute exposure do not cause a tissue damage or metabolic change in $P$. vimboides at used dilutions.

Copper bioaccumulation. The main sources of copper and nickel in WSF were the crude oil used to produce the diesel combustible and the additives added to the diesel formulation (Silveira et al., 2006). In the present study, copper was one of the more abundant metals in WSF, which suggests a great potential to accumulate in the gills of the organisms tested. Due to the direct exposure of the gills to the contaminants present in aquatic environments, this organ is considered the first choice in the analysis and monitoring of water pollution. However, the present results showed that the metal did not accumulate in the fish analyzed. It is possible that contact with metals activates the hypersecretion of gill mucus, which is a protection mechanism against metal absorption by chelation (i.e., the formation of a copper complex to reduce the metal's toxicity) (Heath, 1995). Probably the metal concentration in the WSF does not produce a toxic effect in P. vimboides.

The frequencies of damaged cells and the CS obtained in the Comet assay were greater in lower dilutions and increase with exposure times (24- and 96-h). The micronucleus test, AST and ALT were not efficient at detecting contamination by WSF in $P$. vimboides under acute exposure. No copper bioaccumulation was observed in $P$. vimboides. Finally, the genotoxic effects of WSF in the cells were the most evident in $P$. vimboides during acute exposure.

\section{Acknowledgments}

The authors would like to thank Mr. Vittorio Correia Junior, Instituto Federal de Colatina, for donating the fish and LabPetro- DQUI/UFES for the copper analysis. This work was supported by a research grant from an independent UVV/ FUNDADESP project. LC Gomes is a research fellowship recipient from CNPq/Brazil (Process: \#308782/2011-9).

\section{Literature Cited}

Adeyemi, O., O. B. Oloyede, A. T. Oladiji \& E. A. Adebayo. 2009. Effect of water contaminated with phthalate, benzene and cyclohexane on Clarias gariepinus cellular system. Food and Chemical Toxicology, 47: 194-944.

Al-Sabati, K. \& C. D. Metcalfe. 1995. Fish micronuclei for assessing genotoxicity in water. Mutation Research, 343: 121-135.

Buschini, A., A. Martino, B. Gustavino, M. Monfrinotti, P. Poli, C. Rossi, M. Santoro, A. J. M. Dörr \& M. Rizzoni. 2004. Comet 
assay and micronucleus test in circulating erythrocytes of Cyprinus carpio specimens exposed in situ to lake waters treated with disinfectants for potabilization. Mutation Research, 557: 119-129.

Collins, R. A., M. Ai-Guo \& S. J. Duthie. 1995. The kinetics of repair of oxidative DNA damage (strand breaks and oxidised pyrimidines) in Human Cells. Mutation Research, 336: 69-77.

Çavas, T. \& S. G. Ergene. 2003. Evaluation of the genotoxic potential of lambda-cyhalothrin using nuclear and nucleolar biomarkers on fish cells. Mutation Research, 534 : 93-99.

Çavas, T., N. N. Garanko \& V. V. Arkhipchuk. 2005. Induction of micronuclei and binuclei in blood, gill and liver cells of fishes subchronically exposed to cadmium chloride and copper sulphate. Food and Chemical Toxicology, 43: 569-574.

Dangé, A. D. 1986. Metabolic effects of naphthalene, toluene or phenol intoxication in the cichlid fish tilapia, Oreochromis mossambicus: changes in aminotransferase activities. Environmental Pollution, 42: 311-323.

Ergene, S., T. Çavas, A. Çelik, N. Köleli, F. Kaya \& A. Karahan. 2007. Monitoring of nuclear abnormalities in peripheral erythrocytes of three fish species from the Goksu Delta (Turkey): genotoxic damage in relation to water pollution. Ecotoxicology, 16: 385-391.

Fenech, M., W. P. Chang, M. Kirsch-Volders, N. Holland, S. Bonassi \& E. Zeiger. 2003. Human project: detailed description of the scoring criteria for the cytokinesis block micronucleus assay using isolated human lymphocyte cultures. Mutation Research, 534: 65-75.

Frenzilli, G., V. Scarelli, I. Del Barga, M. Nigro, L. Förling, C. Bolognesi \& J. Sturve. 2004. DNA in eelpout (Zoarces viviparous) from Göteborg harbour. Mutation Research, 552: 187-195.

Gomes, L. C., A. R. Chippari-Gomes, R. N. Oss, L. F. L. Fernandes \& R. A. Magris. 2009. Acute toxicity of copper and cadmium for piauçu, Leporinus macrocephalus, and curimatã, Prochilodus vimboides. Acta Scientiarum. Biological Science, 31: 313-315.

Heath, A. G. 1995. Water pollution and fish physiology. $2^{\text {nd }} \mathrm{ed}$. CRC Press, Lewis publishers, 342p.

Kennedy, C. J. \& A. P. Farrell. 2005. Ion homeostasis and interregnal stress responses in juvenile Pacific herring, Clupea pallasi, exposed to the water-soluble fraction of crude oil. Journal of Experimental Marine Biology and Ecology, 323: 43-56.

Kobayashi, H., Y. Sugiyama, M. Morikawa, T. Hayashi \& A. Sofuni. 1995. Comparison between manual microscopic analysis and computerized image analysis in the single cell gel electrophoresis, MMS Communication, 3: 103-115.

Jha, A. N. 2008. Review: Ecotoxicological applications and significance of the comet assay. Mutagenesis, 23: 207-221.

Lee, R. F. \& J. W. Anderson. 2005. Significance of cytochrome P450 system responses and levels of bile fluorescent aromatic compounds in marine wildlife following oil spills. Marine Pollution Bulletin, 50: 705-723.

Lemos, N. G., A. L. Dias, A. T. Silva-Souza \& M. S. Mantovani, 2005. Evaluation of environmental waters using the Comet assay in Tilapia rendalli. Environmental Toxicology and Pharmacology. 19: 197-201.

Maria, V. L., A. C. Correia \& M. A. Santos. 2004. Genotoxic and biochemical responses in caged eel (Anguilla anguilla L.) after short-term exposure to harbour waters. Environment International, 29: 923 - 929.

Mitchelmore, C. L. \& J. K. Chipman. 1998. Detection of DNA strand breaks in brown trout (Salmo salar) hepatocytes and blood cells using the single cell gel electrophoresis (comet) assay. Aquatic Toxicology, 41: 161-182.

Nickum, J., G. H. L. Bart, P. R. Bowser, I. E. Greer, C. Hubbs, J. A. Jenkins, J. R. MacMillan, J. W. Rachlin, J. D. P. W. Rose Sorensen \& J. R. Tomasso. 2004. Guidelines for the use of fishes in research. American Fisheries Society, Bethesda, MD.

Pandrangi, R., M. Petras, S. Ralph \& M. Vrzoc. 1995. Alkaline Single Cell Gel (comet) assay and genotoxicity monitoring using bulheads and carp. Environmental and Molecular Mutagenesis, 26: $345-356$.

Rodrigues R. V., K. C. Miranda-Filho, E. P. Gusmão, C. B. Moreira, L. A. Romano \& L. A. Sampaio. 2010. Deleterious effects of water-soluble fraction of petroleum, diesel and gasoline on marine pejerrey Odontesthes argentinensis larvae. Science of the Total Environment, 408: 2054-2059.

Saeed T. \& T. Al-Mutairi. 1999. Chemical composition of the watersoluble fraction of leaded gasolines in sea water. Environment International, 25: 117-29.

Santos, C. E., L. S. Novaes \& L. C. Gomes. 2010. Genotoxic effects of the diesel water-soluble fraction on the seahorse Hippocampus reidi (Teleostei: Syngnathidae) during acute exposure. Zoologia, 27: 956-960.

Silveira, E. L. C., L. B. Caland, C. V. R. Moura \& E. M. Moura. 2006. Determinação de contaminantes em óleos lubrificantes usados e em esgotos contaminados por esses lubrificantes. Química Nova, 29: 1193-1197.

Simonato, J. D., C. L. B. Guedes \& C. B. R. Martinez. 2008. Biochemical, physiological, and histological changes in the neotropical fish Prochilodus lineatus exposed to diesel oil. Ecotoxicology and Environmental Safety, 69: 112-120.

Singer, M. M., D. Aurand, G. E. Bragin, J. R. Clarks, G. M. Coelho, M. Sowby, L. Tjeerdema. 2000. Standardization of the Preparation and Quantitation of Water accommodated Fractions of Petroleum for Toxicity Testing. Marine Pollution Bulletin, 40: 1007-1016.

Speit, G. \& A. Hartmann. 1995. The contribution of excision repair to the DNA effects seen in the alkaline single cell gel test (Comet assay). Mutagenesis, 10: 555-559.

Teles, M., M. Pacheco \& M. A. Santos. 2003. Anguilla anguilla L. liver EROD, GST, erythrocytic nuclear abnormalities and endocrine responses to naphthalene and $\alpha$-naphthoflavone. Ecotoxicology and Environmental Safety, 55: 98-107.

Tice, R. R., E. Agurell, D. Anderson, B. Burlinson, A. Hartmann, H. Kobayashi, Y. Miyamae, E. Rojas, J. C. Ryu \& Y. F. Sasaki. 2000. Single cell gel/Comet assay: Guidelines for in vitro and in vivo genetic toxicology testing. Environmental and Molecular Mutagenesis, 35: 206-221.

Udroiu, I. 2006. The micronucleus test in piscine erythrocytes. Aquatic Toxicology, 79: 201-204.

Vanzella, T. P., C. B. R. Martinez \& I. M. S. Cólus. 2007. Genotoxic and mutagenic effects of diesel oil water soluble fraction on a neotropical fish species. Mutation Research, 63: 36-43.

Zhang, J. F., X. R. Wang, H. Y. Guo, J. C. Wu \& Y. Q. Xue. 2004. Effects of water-soluble fractions of diesel oil on the antioxidant defenses of the goldfish, Carassius auratus. Ecotoxicology and Environmental Safety, 58: 110-116.

Submitted July 14, 2011

Resumitted July 29, 2012

Accepted October 19, 2012 by Adalberto Luis Va

Published March 31, 2013 